\begin{tabular}{|c|c|c|c|c|}
\hline Submission & Review Process & Revised & Accepted & Published \\
\hline $5-12-2019$ & $11-12 \mathrm{~s} / \mathrm{d} 26-12-2019$ & $25-12-2019$ & $30-12-2019$ & $25-01-2020$ \\
\hline
\end{tabular}

Ampera: A Research Journal on Politics and

Islamic Civilization, Vol. 1 No. 1, Januari 2020 (61-70)

Published by: Politik Islam Universitas Islam Negeri Raden Fatah Palembang

\title{
Analisis Framing Terhadap Berita Pemilihan Gubernur Sumatera Selatan Tahun 2018 di Koran Sumatera Ekspres
}

\author{
Candra Kirana \\ Program Studi Politik Islam Universitas Islam Negeri Raden Fatah Palembang \\ c.kirana@gmail.com \\ Yulion Zalpa \\ Program Studi Ilmu Politik Universitas Islam Negeri Raden Fatah Palembang \\ zalpayulion@gmail.com
}

\begin{abstract}
This paper will parse and explain the role of media in the Election of the Governor of South Sumatra in 2018. The media to be examined is the local media namely the Harian Sumatera Ekspres (Sumeks). Harian Sumeks is one of the media that dominates readers in south sumtra province. With such a position, of course, Sumeks has influence in building opinions in society.

The theory used in this study is the framing theory of Zhongdan Pan and Gerald M.Kosicki models, This theory in analyzing data operationalizes the four structural dimensions of news teks as a framing device, namely syntax, script, thematic, and rhetorical. This research is a qualitative study using documents as the main data source.

The results of this study indicate that Sumeks described the four participants of the South Sumtra Governor Election in 2018 as well. If at first galnce, it will be difficult to find out which candidate pairs are more inclined. However, when using framing theory, it can be seen that Sumeks tries to emphasize Dodi-Giri more than other pairs. In addition, it can be concluded that the way Sumeks displays each candidate get a good response from each candidate team because the framing that is built seems to favor all candidates so that this impacts on the number of incoming advertisements.
\end{abstract}

Keywords: harian sumeks, election of the governor of south sumatra in 2018, framing media 


\begin{abstract}
Abstrak
Tulisan ini akan mengurai dan menjelaskan peran media cetak dalam Pemilihan Gubernur Sumatera Selatan tahun 2018. Media yang akan dikaji adalah media cetak lokal Harian Sumatera Ekspres (Sumeks). Harian Sumeks merupakan salah satu media cetak yang mendominasi pembaca di Provinsi Sumatera Selatan. Dengan posisi yang seperti itu, tentunya Sumeks memiliki pengaruh dalam membangun opini dalam masyarakat.

Adapun teori yang digunakan dalam penelitian ini adalah teori framing model Zhongdan Pan dan Gerald M.Kosicki. Teori ini dalam menganalisis data mengoperasionalisasikan empat dimensi struktural teks berita sebagai perangkat framing yaitu sintaksis, skrip, tematik, dan retoris. Penelitian ini merupakan penelitian kualitatif dengan menggunakan dokumen sebagai sumber data utama.

Hasil dari penelitian ini menunjukkan bahwa Sumeks menggambarkan empat peserta Pemilihan Gubernur Sumatera Selatan tahun 2018 secara baik. Jika dilihat sekilas maka akan sulit untuk mengetahui kepada paslon mana Sumeks lebih condong. Namun ketika menggunakan teori framing dapat diketahui bahwa Sumeks berusaha lebih menonjolkan paslon Dodi-Giri dari pada paslon lainnya. Selain itu, dapat disimpulkan bahwa cara Sumeks menampilkan setiap paslon mendapatkan respon yang baik dari setiap calon karena framing yang dibangun seolah-olah memihak kepada semua calon (netral) sehingga hal ini berimbas pada banyaknya iklan yang masuk.
\end{abstract}

Keywords: sumeks, pilgub sumsel 2018, media framing

\title{
PENDAHULUAN
}

Kontestasi pemilihan kepala daerah merupakan ajang lima tahunan yang terjadi di hampir seluruh wilayah Indonesia. Karena besarnya event ini serta sarat dengan kepentingan maka tidaklah mengherankan jika setiap kandidat menggerakkan seluruh sumber daya yang ada untuk memenangkan pemilihan ini termasuk menggunakan media. Pada 27 Juni 2018, Provinsi Sumatera Selatan mengadakan pemilihan kepala daerah serentak. Namun pada penelitian ini, peneliti hanya akan mengkaji terkait peran media dalam menggambarkan atau memberitan setiap pasangan calon peserta pemilihan gubernur Sumsel 2018. Adapun media yang akan peneliti jadikan obyek penelitian adalah media cetak Sumatera Ekspres (Sumeks).

Interaksi yang terjadi antara media dan politik telah banyak kita saksikan terutama menjelang Pilkada. Transaksi yang terjadi biasanya seperti menyediakan space iklan politik, meliput pelantikan pejabat daerah, hingga publikasi yang memblow-up aktifitas kampanye di Pilkada atau dalam kondisi lebih parah lagi terkadang ada juga media yang ditunggangi aktor politik untuk menjatuhkan lawan politik nya. (Yahya, 2019)

Untuk membaca ataupun menganalisis pemberitaan yang dilakukan Sumeks maka peneliti menggunakan teori framing model Zhongdan Pan dan Gerald M.Kosicki. Dalam perspektif komunikasi, analisis framing dipakai untuk membedah cara-cara atau ideologi media saat mengkonstruksi fakta. Analisis ini mencermati strategi seleksi, penonjolan, dan pertautan fakta ke dalam berita agar lebih bermakna, lebih menarik, lebih berarti atau lebih di ingat, untuk menggiring interpretasi khalayak sesuai perspektifnya. Dengan kata lain, framing adalah pendekatan untuk mengetahui bagaimana perspektif atau cara pandang yang digunakan oleh wartawan ketika 
menyeleksi isu dan menulis berita. Cara pandang atau prspektif itu pada akhirnya menentukan fakta apa yang diambil, abgian mana yang ditonjolkan dan dihilangkan, serta hendak dibawa kemana berita tersebut.

Dengan demikian, permasalahan yang diangkat dalam penelitian ini adalah bagaimana koran Sumatera Ekspres membentuk frame berita terhadap setiap pasangan calon peserta Pemilihan Gubernur Sumatera Selatan 2018.

\section{METODE PENELITIAN}

Dalam penelitian ini peneliti menggunakan teori analisis framing model Zhongdan Pan dan Gerald M.Kosicki yang beranggapan bahwa berita yang disajikan merupakan hasil dari konstruksi media. Adapun pendekatan yang digunakan dalam penelitian ini adalah pendekatan kualitatif serta menggunakan berita-berita koran Sumeks yang terbit pada 10 Januari 2018, 13 Februari 2018, 15 Maret 2018, 22 Juni 2018, 23 Juni 2018, 27 Juni 2018, dan 29 Juni 2019 sebagai obyek penelitian.

Data-data yang telah dikumpulkan akan peneliti analisi menggunakan teori framing model Zhongdan Pan dan Gerald M.Kosicki yang mengoperasionalisasikan empat dimensi struktural teks berita sebagai perangkat framing, yaitu sintaksis, skrip, tematik, dan retoris. Sintaksis adalah cara wartawan menyusun berita, skrip adalah cara wartawan mengisahkan fakta, tematik adalah cara wartawan menuliskan fakta dan retoris adalah cara wartawan menekankan fakta.

\section{HASIL DAN PEMBAHASAN}

\section{Kontruksi Realitas Sosial}

Salah satu fungsi atau pun kebiasaan dari media massa dalam memberitakan sebuah peristiwa adalah memberikan penafsiran dan juga komentar atas peristiwa tersebut. Maka dari itu media massa memiliki peran penting dalam mengkontruksi realitas yang muncul dalam masyarakat. Singkatnya, peristiwa yang ada kemudian disajikan oleh media massa dengan diberikan penekanan-penekanan pada sisi tertentu akan membuat pembaca memiliki kesan yang kuat terhadap sisi yang berusaha ditonjolkan. (Denis, 2011)

Adapun teori kontruksi realitas sosial pertama kali dicetuskan oleh Peter Berger dan Thomas Luckmann dalam bukunya yang berjudul The Social Construction of Reality, yang artinya "pembentukan realitas sosial". Peter Berger dan Thomas Luckmann mengatakan bahwa pengertian dan pemahaman kita terhadap sesuatu muncul akibat komunikasi dengan orang lain. Realitas sosial sesungguhnya tidak lebih dari sekedar hasil konstruksi sosial dalam komunikasi tertentu. (Alvin, 1981)

Menurut Saussure, persepsi dan pandangan kita tentang realitas, dikontruksikan oleh katakata dan tanda-tanda lain yang digunakan dalam konteks sosial. Media massa adalah salah satu sarana komunikasi. Dan pekerjaan media pada hakikatnya adalah mengkonstruksikan realitas. Isi media adalah hasil para pekerja media mengkonstruksikan berbagai realitas yang dipilihnya, misalnya realitas politik. Oleh karena sifat dari pekerjaan media massa adalah menceritakan peristiwa-peristiwa, maka seluruh isi media adalah realitas yang telah dikonstruksikan.

Pembuatan berita di media pada dasarnya tak lebih dari penyusunan realitas-realitas hingga membentuk sebuah "cerita". Isi media adalah hasil konstruksi realitas dengan bahasa sebagai 
perangkat dasarnya. Sedangkan bahasa bukan saja sebagai alat yang merepresentasikan realitas, namun juga bisa menentukan relief seperti apa yang akan diciptakan oleh bahasa tentang realitas tersebut. Akibatnya, media massa mempunyai peluang yang sangat besar untuk mempengaruhi makna dan gambaran yang dihasilkan dari realitas yang dikonstruksikan.

Setiap upaya "menceritakan" sebuah peristiwa, keadaan, benda, atau apapun, pada hakikatnya adalah usaha mengkonstruksikan realitas. Seorang aktivis mahasiswa yang baru saja pulang usai melakukan demo atau unjuk rasa di Gedung MPR/DPR, lalu menceritakan keadaan dirinya atau pengalamannya, pada dasarnya ia mengkonstruksi realitas dirinya itu. Begitu pula dengan profesi wartawan. Pekerjaan utama wartawan adalah mengisahkan hasil liputannya kepada khalayak. Dengan demikian mereka selalu terlibat dengan usaha-usaha mengkonstruksikan realitas, yakni menyusun fakta yang dikumpulkannya ke dalam suatu bentuk laporan jurnalistik berupa berita, karangan khas, atau gabungan keduanya. (Mikail, 2016)

\section{Teori Framing}

Untuk menganalisis berita-berita yang telah peneliti tentukan yang diterbitkan oleh koran Sumatera Ekspres, peneliti menggunakan teori Analisis framing model Zhongdan Pan dan Gerald M. Kosicki. Model ini peneliti anggap lebih dapat menjelaskan dan menguraikan frame yang coba dibentuk oleh media. Menurut Zhongdan Pan dan Gerald M. Kosicki yang dikutip oleh Sobur, analisis framing mengoperasionalisasikan empat dimensi struktural teks berita sebagai perangkat framing, yaitu sintaksis, skrip, tematik, dan retoris. Keempat dimensi struktural ini membentuk semacam tema yang mempertautukan elemen-elemen semantik narasi berita dalam suatu koherensi global. Model ini berasumsi bahwa setiap berita mempunyai frame yang berfungsi sebagai pusat organisasi ide. Frame merupakan suatu ide yang dihubungkan dengan elemen yang berbeda dalam teks berita ke dalam teks secara keseluruhan. Frame berhubungan dengan makna. Bagaimana seseorang memaknai suatu peristiwa, dapat dilihat dari perangkat tanda yang dimunculkan dalam teks. (Eriyanto, 2011)

Dalam pendekatan ini perangkat framing dibagi menjadi empat struktur besar. Pertama struktur sintaksis, kedua struktur skrip, ketiga struktur tematik, keempat struktur retoris. Struktur sintaksis bisa diamati dari bagan berita. Sintaksis berhubungan dengan bagaiamana wartawan menyusun peristiwa (pernyataan, opini, kutipan, pengamatan atas peristiwa) ke dalam bentuk susunan kisah berita. Dengan demikian, struktur sintaksis ini bisa diamati dari bagan berita (headline yang dipilih, lead yang dipakai, latar informasi yang dijadikan sandaran, sumber yang dikutip, dan sebagainya). Struktur skrip melihat bagaimana strategi bercerita atau bertutur yang dipakai wartawan dalam mengemas peristiwa. Kemudian, struktur tematik berhubungan dengan cara wartawan mengungkapkan pandangannya atas peristiwa kedalam proposisi, kalimat, atau hubungan antarkalimat yang membentuk teks secara keseluruhan. struktur ini akan melihat bagaimana pemahaman itu diwujudkan kedalam bentuk yang lebih kecil. Sedangkan struktur retoris berhubungan dengan cara wartawan menekankan arti tertentu. Dengan kata lain, struktur retoris melihat pemakaian pilihan kata, idiom, grafik, gambar, yang juga dipakai guna memberi penekanan pada arti tertentu. 
Kerangka Framing Pan dan Kosicki

\begin{tabular}{|c|c|c|}
\hline STRUKTUR & PERANGKAT FRAMING & UNIT YANG DI AMATI \\
\hline $\begin{array}{l}\text { SINTAKSIS } \\
\text { Cara wartawan } \\
\text { menyusun } \\
\text { berita }\end{array}$ & 1. Skema berita & $\begin{array}{l}\text { Headline, lead, latar } \\
\text { informasi, kutipan, sumber, } \\
\text { pernyataan, penutup. }\end{array}$ \\
\hline $\begin{array}{l}\text { SKRIP } \\
\text { Cara wartawan } \\
\text { mengisahkan } \\
\text { fakta }\end{array}$ & 2. Kelengkapan berita & $5 \mathrm{~W}+1 \mathrm{H}$ \\
\hline $\begin{array}{l}\text { TEMATIK } \\
\text { Cara wartawan } \\
\text { menulis fakta }\end{array}$ & $\begin{array}{ll}\text { 3. Detail } & \\
\text { 4. Maksud kalimat, } \\
\text { hubungan } \\
\text { 5. Nominalisasi antar } \\
\text { kalimat } \\
\text { 6. Koherensi } \\
\text { 7. Bentuk kalimat } \\
\text { 8. Kata ganti } \\
\end{array}$ & Paragraf, proposisi \\
\hline $\begin{array}{l}\text { RETORIS } \\
\text { Cara wartawan } \\
\text { menekankan } \\
\text { fakta }\end{array}$ & $\begin{array}{l}\text { 9. Leksikon } \\
\text { 10. Grafis } \\
\text { 11. Metafora } \\
\text { 12. Pengandaian }\end{array}$ & $\begin{array}{l}\text { Kata, idiom, gambar/foto, } \\
\text { grafik }\end{array}$ \\
\hline
\end{tabular}

\section{Analisis Framing}

Dari tanggal-tanggal terbit yang telah peneliti tentukan, maka di dapatlah beberapa berita berikut yang sesuai dengan topik bahasan peneliti.

\begin{tabular}{|l|l|l|}
\hline No & Hari dan Tanggal Terbit & Anak Judul Berita \\
\hline 1 & Rabu, 10 Januari 2018 & $\begin{array}{l}\text { 1. Kandidat Mulai Obral Janji: DPT } \\
\text { Pilgub Sumsel Tembus 6 Juta } \\
\text { 2. Ishak-Yudha Deklarasi dan Daftar ke } \\
\text { KPU Sumsel (Society Biz) }\end{array}$ \\
\hline 2 & Selasa, 13 Februari 2018 & $\begin{array}{l}\text { 3. Janji Jual Program } \\
\text { 4. Dodi Tumbuhkan Harapan Baru } \\
\text { (Society Biz) }\end{array}$ \\
\hline 3 & Kamis, 15 Maret 2018 & $\begin{array}{l}\text { 5. Infrastruktur-Karet Bikin Panas: } \\
\text { Kandidat Saling Serang, Mic Jadi } \\
\text { Kendala }\end{array}$ \\
\hline 4 & Jum'at, 22 Juni 2018 & $\begin{array}{l}\text { 6. Pengamat Nilai Program Kerja } \\
\text { Paslon Tak Konkret }\end{array}$ \\
\hline
\end{tabular}




\begin{tabular}{|c|c|c|}
\hline 5 & Sabtu, 23 Juni 2018 & $\begin{array}{l}\text { 7. Aswari-Irwansyah Disebut "Kuda } \\
\text { Hitam" } \\
\text { 8. Kuasai Materi, Program Paling } \\
\text { Realistis } \\
\text { 9. Program Ishak-Yudha Direspons } \\
\text { Positif } \\
\text { 10. Yakin Sumsel Bakal Lebih Maju }\end{array}$ \\
\hline 6 & Rabu, 27 Juni 2018 & $\begin{array}{l}\text { 11. Siap Menang, Siap Kalah } \\
\text { 12. Timses Saling Lapor Pelanggaran } \\
\text { 13. Restu Ayah Bunda Iringi Langkah } \\
\text { Yudha Pratomo Mahyuddin PhD } \\
\text { (Society Biz) }\end{array}$ \\
\hline 7 & Jum'at, 29 Juni 2018 & $\begin{array}{l}\text { 14. Real Count KPU, Sementara HD-MY } \\
\text { Unggul } \\
\text { 15. Temukan Dugaan Praktik Money } \\
\text { Politics } \\
\text { 16. Kawal Suara, Turunkan Tim }\end{array}$ \\
\hline
\end{tabular}

Berita-berita diatas akan peneliti analisis menggunakan Teori Framing Model Zhongdan Pan dan Gerald M.Kosicki. Dalam pendekatan ini perangkat framing dibagi menjadi empat struktur besar, yaitu struktur sintaksis, struktur skrip, struktur tematik dan terakhir struktur retoris.

Setelah di analisis dari segi struktur sintaksis, bagian-bagian berita membentuk suatu skema berita yang menjadi pedoman bagaimana fakta akan dituliskan atau disusun. Bentuk sintaksis yang paling populer adalah struktur piramida terbalik. Artinya dalam bentuk piramida terbalik, bagian awal berita atau bagian atas berita ditampilkan lebih penting dibandingkan dengan bagian bawahnya.

Dari berita yang telah peneliti analisis melalui salah satu perangkat framing dari model Pan dan Kosicki, yaitu struktur sintaksis, peneliti menyimpulkan adanya keterkaitan antar berita, namun dalam hal ini peneliti akan membuat dua kelompok berita yang memiliki skema yang berbeda. Kelompok pertama, berita yang diterbitkan sebelum debat pertama dan kelompok kedua berita yang terbit setelah debat pertama. Dalam kelompok pertama frame yang coba dibangun adalah kualitas dari sosok paslon nomor 3 Ishak-Yudha dan paslon nomor 4 Dodi-Giri.

Frame yang hendak dibangun pada diri Ishak-Yudha adalah keserasian paslon, Ishak digambarkan sosok yang telah berpengalaman dan Yudha digambarkan sebagai sosok yang berpendidikan tinggi dan berasal dari kalangan muda atau milenial. Sedangkan frame yang hendak dibangun pada diri Dodi adalah merupakan sosok bupati yang sukses membangun Muba dalam masa waktu jabatan 1 tahun, dan sangat di dukung masyarakat Muba dalam pencalonannya.

Kelompok berita kedua, frame yang hendak dibangun adalah program kerja Dodi-Giri yang realistis dan bersih dari pelanggaran. Program Dodi-Giri digambarkan oleh penulis lebih masuk akal dalam berita yang dimuat pasca debat pertama, setelah itu dikuatkan pula pada berita berikutnya pasca debat kedua selain itu paslon ini dianggap lebih menguasai materi debat dan mengesampingkan kejadian mati lampu yang membuat paslon ini memiliki waktu untuk berpikir, karena pada saat mati lampu merupakan bagian paslon Dodi-Giri untuk berbicara. 
Adapun pemberitaan terkait paslon lain, tetap ada walaupun dengan porsi yang seadanya saja. Dalam membuat berita, Sumeks tidak menggambarkan secara nyata keberpihakannya pada kandidat tertentu, alhasil semua peserta Pilgub memasang iklan di koran Sumatera Ekspres. Pada rubrik Society Biz yang notebene merupakan berita yang berbayar ditemukan hanya ada dua paslon Pilgub yang menggunakannya, yakni paslon nomor urut 3 dan paslon nomor urut 4.

Dari pengamatan melalui struktur skrip, yakni mengamati bagaimana pengisahan peristiwa ke dalam berita. Dapat peneliti simpulkan ada dua gaya pemberitaan yang dilakukan oleh penulis (Sumeks). Gaya pertama, yakni memberikan porsi pemberitaan kepada seluruh kandidat dalam satu berita yang sama. Walaupun dalam hal ini unsur berita lebih banyak condong ke paslon DodiGiri. Gaya kedua adalah, memberitakan setiap kandidat pilgub dalam berita yang berbeda-beda. Artinya, paslon HD-MY memiliki berita nya sendiri, paslon Asri memiliki beritanya sendiri, paslon Ishak-Yudha memiliki berita sendiri, dan paslon Dodi-Giri memiliki berita nya sendiri. Dalam berita gaya kedua ini dapat dikatakan pemberitaan yang bertujuan untuk membranding setiap paslon.

Setiap berita yang dituliskan memiliki temanya masing-masing. Keunikan dari berita yang dibuat oleh Sumeks. Secara sekilas dilihat tidak memihak paslon mana pun. Sumeks tetap menjaga tema nya untuk tidak untuk menjelek-jelekkan paslon lain atau untuk menjatuhkan paslon lain. Sumeks lebih banyak membuat berita tentang satu paslon saja dalam setiap berita. Namun kadar makna dalam setiap berita berbeda-beda. Dari hasil analisis peneliti menggunakan struktur tematik, pemberitaan yang dilakukan oleh Sumeks, lebih condong ke arah paslon Dodi-Giri.

Dalam pemilihan gambar untuk melengkapi berita dalam rangka menciptakan makna yang lebih kuat, Sumeks melakukan nya hampir dengan sempurna. Hanya saja ada beberapa pemilihan gambar yang tidak tepat di dalam berita yang sangat penting dilakukan penekanan melalui gambar. Sehingga dari analisis menggunakan struktur retoris, posisi Sumeks sedikit lebih dekat ke paslon Dodi-Giri.

\section{KESIMPULAN}

Dari analisis yang telah dilakukan oleh peneliti menggunakan teori framing model Pan dan Kosicki dapat ditemukan perbedaan dalam penyajian berita. Pada berita yang dimuat pada rubrik Society Biz, dari sampel yang ditentukan, peneliti hanya menemukan paslon Ishak-Yudha dan Dodi-Giri yang pernah memenuhi rubrik tersebut. Untuk paslon HD-MY dan Aswari Irwansyah, tidak ditemukan berita tentang mereka di rubrik Society Biz. Tetapi untuk space iklan, semua paslon Pilgub Sumsel 2018 memasang iklan di koran Sumatera Ekspres.

Ada keterkaitan antara pemasang berita berbayar (Society Biz) dengan keputusan politik yang diambil oleh Sumeks. Dengan sikap yang tidak terlalu terang-terangan memihak paslon tertentu, mampu membawa keuntungan secara ekonomi bagi Sumeks. Karena semua paslon memasang iklan untuk mempromosikan diri mereka di Sumeks.

Untuk menyiasati agar keberpihakan tidak terlalu tampak, maka setiap paslon dibuatkan berita tentang mereka masing-masing. Sehingga ketika dilihat, misalnya jika ada berita tentang Ishak-Yudha, maka isinya tentang Ishak-Yudha semua, ada berita tentang Dodi-Giri maka isinya menyangkut Dodi-Giri semua. Artinya berita yang dibuat oleh Sumeks, turut dipertimbangkan akibatnya. Terutama, jika membuat berita yang tidak mengenakkan salah satu pihak, maka kemungkinan salah satu paslon tidak lagi memasang iklan di Sumeks. 
Namun, secara garis besar dengan memperhatikan frame yang diciptakan dalam setiap beritanya, Sumeks lebih cenderung berpihak pada paslon Dodi-Giri. Beberapa frame yang hendak ditampilkan kepada pembaca diantaranya menggambarkan sosok Dodi yang mampu membangun Muba dalam masa satu tahun jabatan, selain itu juga ditampilkan bahwa program Dodi lebih masuk akal/realistis, serta menampilkan bahwa paslon Dodi-Giri merupakan paslon yang dicurangi. 
Candra Kirana \& Yulion Zalpa,Analisis Framing Terhadap Berita Pemilihan Gubernur Sumatera Selatan Tahun 2018 di Koran Sumatera Ekspres, Ampera: A Research Journal on Politics and Islamic Civilization, Vol. 1 No.1, Januari 2020

\section{DAFTAR PUSTAKA}

Eriyanto. 2011. Analisis Framing: Kontruksi, Ideologi, dan Politik Media, Yogyakarta: PT. LKiS Printing Cemerlang.

Mcquail, Denis. 2011. Teori Komunikasi Massa (Buku 1/ Edisi ke-6), Jakarta: Salemba Humanika. Sobur, Alex. 2015. Analisis Teks Media: Suatu Pengantar untuk Analisis Wacana, Analisis Semiotik, dan Analisis Framing. Bandung: PT. Remaja Rosdakarya.

Toffler, Alvin. 1981. The Third Wave. London: Pan Books

\section{Skripsi dan Jurnal}

Chandra, A., Darmawan, E., \& Yesi, Y. (2018). Upaya Komisi Pemilihan Umum Provinsi Sumatera Selatan dalam Meningkatkan Partisipasi Pemilih pada Pilkada Serentak 2018 dan Pemilu Serentak 2019. Jurnal Studi Sosial Dan Politik, 2(1), 12-30. https://doi.org/https://doi.org/10.19109/jssp.v2i1.4061

Darmawan, E., \& Septiana, A. (2019). Analisis Fungsi Partai Politik Pada Pilkada Musi Banyuasin 2017 (Studi Terhadap Partai Politik Pengusung Pasangan Dodi Reza Dan Beni Hernedi). Jurnal Studi Sosial Dan Politik, 3(1), 28-41. https://doi.org/https://doi.org/10.19109/jssp.v3i1.4066

Eriyanto. 2008. Konsentrasi Kepemilikan Media dan Ancaman Ruang Publik: Jurnal Ilmu Sosial dan Ilmu Politik Vol.12 No.2. Yogyakarta: Universitas Gadjah Mada

Flora, Elina. 2014. Analisis Framing Berita Calon Presiden RI 2014-2019 pada Surat Kabar Kaltim Post dan Tribun Kaltim: e-Jurnal Ilmu Komunikasi Vol. 2 No. 3. Program Studi Ilmu Komunikasi, FISIP: Universitas Mulawarman

Hamad, Ibnu. 2010. Media dan Demokrasi di Asia Tenggara: Kasus Indonesia. Depok: Universitas Indonesia

Johanes, Leonardo. 2013. Analisis Framing Pemberitaan Konflik Partai Nasdem di Harian Media Indonesia dan Koran Sindo: Jurnal E-Komunikasi Vol. 1 No.2. Program Studi Ilmu Komunikasi: Universitas Kristen Petra

Kadewandana, Donie. 2008. Kontruksi Realitas di Media Massa (Analisis Framing terhadap Pemberitaan Baitul Muslimin Indonesia PDI-P di Harian KOMPAS dan Republika). Jakarta: UIN Syarif Hidayatullah.

Levina, Xena. 2014. Analisis Framing Terhadap Pemberitaan Sosok Basuki Tjahaja Purnama (AHOK) di Media Online: Jurnal E-Komunikasi Vol. 2. Program Studi Ilmu Komunikasi: Universitas Kristen Petra

Mikail, Kiki. "PEMILU DAN PARTAI POLITIK DI INDONESIA: Menanti Kebangkitan Partai Politik Islam Di Tahun 2019”. Tamaddun: Jurnal Kebudayaan dan Sastra Islam 15, no. 1 (April 7, 2016): 107-148. Accessed February 11, 2020. http://jurnal.radenfatah.ac.id/index.php/tamaddun/article/view/444. 
Pardianto. 2014. Analisis Framing Pemberitaan Pilkada Maluku di Harian Ambon Express dan Rakyat Maluku: Jurnal Komunikasi Islam Vol.04 No.02, Program Studi Komunikasi dan Penyiaran Islam. Fakultas Dakwah dan Komunikasi: UIN Sunan Ampel

Sari, Dewi Prawita. 2013. Analisis Framing Pemberitaan KOMPAS.COM dan VIVANEWS.COM Pada Peristiwa Runtuhnya Terowongan Tambang PT. Freeport Indonesia, COMMONLINE DEPARTEMEN KOMUNIKASI Vol.2 No.2, Jurusan Ilmu Komunikasi, FISIP: Universitas Airlangga

Syarif Zain, Z., \& Ari, A. (2019). The Efforts of Islamic Splinter Movements to Withstand from Heretical Issue in Indonesia: Study of LDII, MTA and Jam'iyyatul Islamiyah. Jurnal Studi Sosial Dan Politik, 3(2), 97-113. https://doi.org/https://doi.org/10.19109/jssp.v3i2.4331

Yahya, A. (2019). Political Communication of Hasan Basri Agus; Dramaturgical Analysis in Jambi Local Government Implementation. Jurnal Studi Sosial Dan Politik, 3(2), 156-165. https://doi.org/https://doi.org/10.19109/jssp.v3i2.4401

Yusuf, Iwan Awaluddin. 2011. Media Lokal dalam Konstelasi Komunikasi Politik di Daerah: Jurnal Ilmu Sosial dan Ilmu Politik Vol.14 No.3.

\section{Koran}

Sumatera Ekspres. Edisi terbit 10 Januari 2018

Edisi terbit 13 Februari 2018

Edisi terbit 15 Maret 2018

Edisi terbit 22 Juni 2018

Edisi terbit 23 Juni 2018

Edisi terbit 27 Juni 2018

. Edisi terbit 29 Juni 2019 